\title{
Response of Brown and White Adipose Tissue to Lipolytic Agents in the Rat during Development
}

\author{
P. HAHN ${ }^{[18,19]}$ \\ Departments of Pediatrics and Obstetrics and Gynecology, University of British Columbia, Vancouver, British Columbia, Canada
}

\begin{abstract}
Extract
Minced samples of brown and white adipose tissue from young rats were incubated with various lipolytic agents. Both tissues responded well to norepinephrine $(10 \mu \mathrm{g} / \mathrm{ml}$ buffer), theophyllin ( 2.5 or $5 \mathrm{mg} / \mathrm{ml}$ ), and dibutyryl cyclic adenosine monophosphate (AMP) $\left(10^{-3} \mathrm{M}\right)$ by releasing glycerol. Brown adipose tissue from newborn rats and rats older than 20 days was responsive to both glucagon and adrenocorticotropic hormone $(\mathrm{ACTH})(10 \mu \mathrm{g} / \mathrm{ml})$, but between days 2 and 20 did not react to these hormones. Responsiveness of brown adipose tissue to ACTH could be induced prematurely by injecting $5 \mathrm{mg}$ cortisone acetate $/ 100 \mathrm{~g}$ body weight on days 8 and 9 . Such injections also enhanced the response to ACTH 30 days later. Subcutaneous white adipose tissue became responsive to glucagon after day 18 but later in life did not react to this hormone. Ovarian and epididymal adipose tissues, however, showed an increase in responsiveness to glucagon.
\end{abstract}

\section{Speculation}

Our results indicate that there are some basic differences in the responsiveness to lipolytic agents not only between brown adipose tissue and white subcutaneous tissue but also between those tissues and epididymal and ovarian fat. It appears that a developmental approach to explain these differences might clarify the mechanisms responsible for differences in the responsiveness of the adenyl cyclases of the various tissues studied.

\section{Introduction}

The fetal rat just before birth has well developed interscapular brown adipose tissue but no white fat. The latter first appears between postnatal days 1 and 2 in the subcutaneous region over the thighs. Both adipose tissues rapidly accumulate fat during further development [6]. This rapid laying down of lipids has been ascribed to the high fat content of the milk [5].

The physiological functions of brown and white adipose tissue appear to be different. Brown fat, particularly in newborn mammals, seems to play an important role in heat production, while white fat serves as an energy store to be used during starvation and other emergencies [7]. It may therefore be expected that the stimuli acting on the two tissues are also different.

Very little is known about the reactivity of adipose tissue to lipolytic hormones during development. As rats age, noradrenaline seems to be less effective [8], but the reason for this is not clear. Other hormones have not been examined; yet it seems likely that a rapidly developing animal on a high fat diet (milk) would react differently than an adult animal. In addition, it was found that the activity of hormone-sensi- 
tive lipase increases [2], while that of lipoprotein lipase decreases with age in the suckling rats [3]. These findings, together with the fact that the activity of phosphodiesterase which breaks down cyclic AMP is also highest in the adipose tissue of very young suckling rats [12], already indicate that we should expect changes in the response of adipose tissue to lipolytic hormones during postnatal development. In this work such changes were examined in white and brown adipose tissue of fetal suckling and weaned rats.

\section{Methods}

In developmental studies it is difficult to use isolated adipose tissue cells since in the youngest age group the lipid content changes considerably and they will not float. It is therefore not feasible to relate results to units of triglyceride content; consequently, minced tissue was used throughout. Brown adipose tissue was obtained from the interscapular region, white adipose tissue from the region above the knees and thighs. In some rats (older than 18 days) epididymal and ovarian adipose tissue was also examined. Tissue was rapidly removed, cut into small pieces with scissors, weighed at room temperature, and then incubated in $2 \mathrm{ml}$ KrebsRinger bicarbonate buffer with half the recommended amount of $\mathrm{Ca}++$, under $95 \%$ oxygen and $5 \% \mathrm{CO}_{2}$ at $37^{\circ}$ for $1 \mathrm{hr}$. The buffer, $\mathrm{pH} 7.4$, always contained 200 $\mathrm{mg} / 100 \mathrm{ml}$ glucose and $4 \%$ bovine albumin fraction IV [13]. The following lipolytic agents were used: glucagon and ACTH [14], both at a dose of $10 \mu \mathrm{g} / \mathrm{ml}$; theophyllin, 5 or $2.5 \mathrm{mg} / \mathrm{ml}$; and dibutyryl cyclic AMP [15], $5 \mathrm{mg} / \mathrm{ml}$.

Glycerol was determined at the end of the incubation period in $0.2 \mathrm{ml}$ buffer after filtering through glass wool to remove the tissue. The medium in which brown adipose tissue had been incubated was immediately placed into boiling water for $5 \mathrm{~min}$ to precipitate the protein and then centrifuged at $10,000 \mathrm{rpm}$ [16].

Glycerol was then determined according to Novak [10] as follows:

Glycerol $+\Lambda \mathrm{TP}-\underset{\text { glycerokinase }}{\longrightarrow}$ alpha-glycero-phosphate $+\Lambda \mathrm{DP}$ ADP + PEP - pyruvato kinase pyruvate + ATP

Pyruvate + NAD - lactate dehydrogenase lactate + NADH

All results are expressed as micromoles glycerol released per gram tissue per hour.

In some cases free fatty acids were also determined by the method of Novak [9]. Since results did not differ from those obtained with glycerol they are not shown here.
Animals were killed in the morning (10 AM) after feeding, the stomachs always contained milk or solid food.

\section{Results}

The rate of spontaneous glycerol release in brown adipose tissue increased with age, whereas in white adipose tissue the rate was highest in the youngest animals (Fig. 1). Thus, in rats younger than 18-20 days, more glycerol was released by white than by brown adipose tissue, while after that age the opposite was true.

The dibutyryl derivative of cyclic AMP became slightly more effective with age in brown but not in white adipose tissue (Fig. 2). Both theophyllin, which

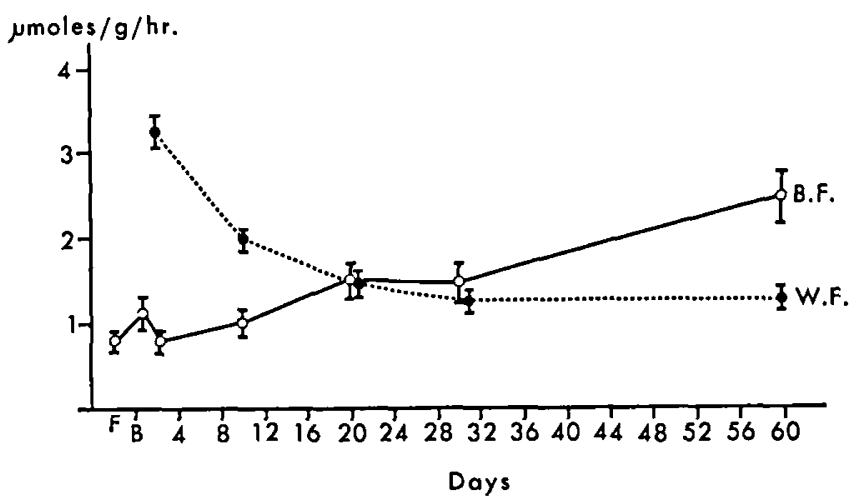

Fig. 1. Spontaneous rate of glycerol relcase in white and brown adipose tissue of rats during development. Abscissa: age in days. F: Fetus (20-21 days after conception). B: Birth. Ordinate: $\mu$ moles glycerol $/ \mathrm{hr} / \mathrm{g}$ tissue. B.F.: Brown fat. W.F.: White fat. Each point is the mean of 5-10 determinations \pm SE.

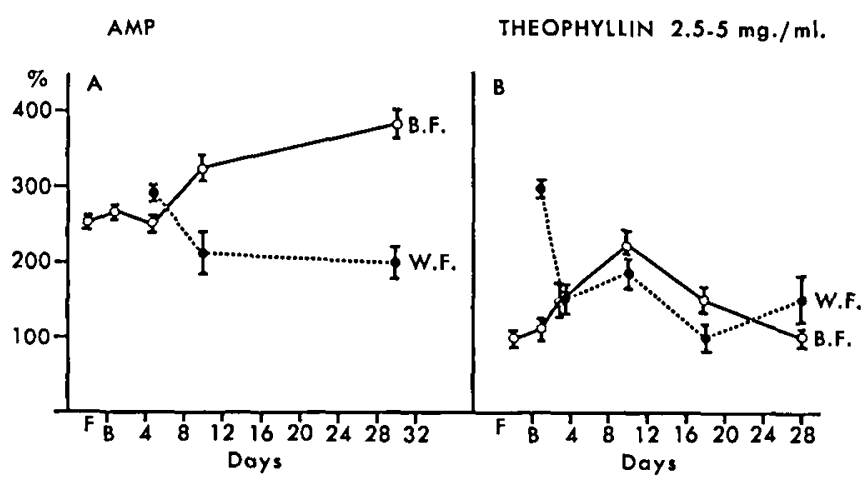

Fig. 2. Effect of dibutyryl cyclic AMP and theophyllin on glycerol release by white and brown adipose tissue. Abscissa: Age in days. F: Fetus. B: Birth. Ordinate: Percentage increase in rate of glycerol release over control values. Each point is the mean of 4-6 determinations. $A$ : Addition of $10^{-8} \mathrm{M}$ dibutyryl cyclic AMP. $B$ : Addition of 5 or $2.5 \mathrm{mg}$ theophyllin $/ \mathrm{ml}$ buffer. 
inhibits phosphodiesterase activity, and cyclic AMP elicit the largest response in very young white adipose tissue.

Glucagon increased the rate of glycerol release in 1-day-old rats, but both brown and white adipose tissue did not react to this hormone even when the dose was increased to $20 \mu \mathrm{g} / \mathrm{ml}$ between about days 2 and 20 (Fig. 3). After that age all types of adipose tissue gradually become sensitive, excepting subcutaneous white adipose tissue, which seems to react to glucagon only for a limited period between days 20 and 40 .

Brown adipose tissue did not react to ACTH after day 3, but white adipose tissue did (Fig. 4). In epididymal adipose tissue the response to glucagon increased with age, while the response to ACTH remains unaltered (Figs. 3 and 4).

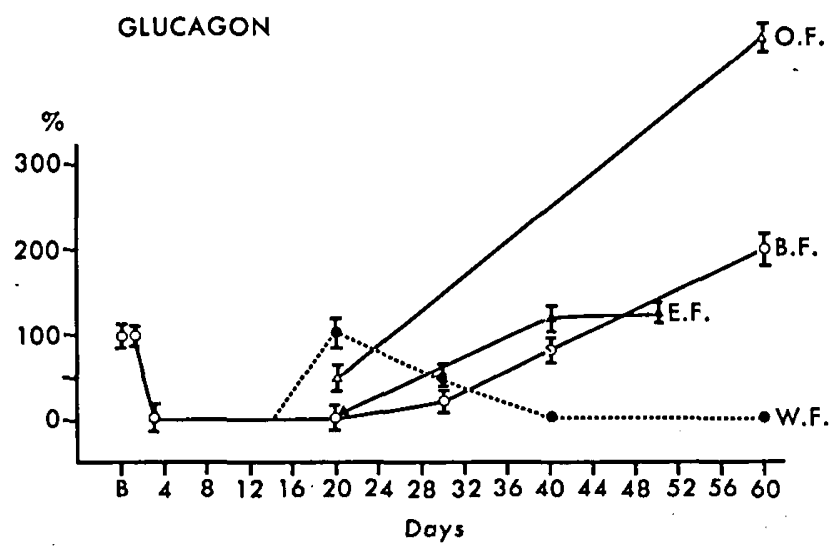

Fig. 3. Effect of $10 \mu \mathrm{g}$ glucagon/ml buffer on glycerol release by white and brown adipose tissue. Abscissa: Age in days. B: Birth. Ordinate: Percentage increase in rate of glycerol release over control values. Each point is the mean of 4-6 determinations.

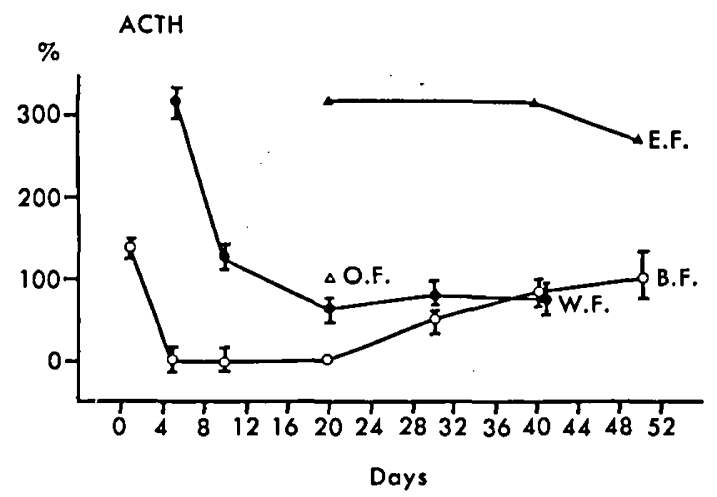

Fig. 4. Effect of $10 \mu \mathrm{g} / \mathrm{ml} \mathrm{ACTH} \mathrm{on} \mathrm{glycerol} \mathrm{release} \mathrm{by} \mathrm{white}$ and brown adipose tissue. Abscissa: Age in days. O: Birth. Ordinate: Percentage in rate of glycerol release over control values. Each point is the mean of 4-6 determinations.

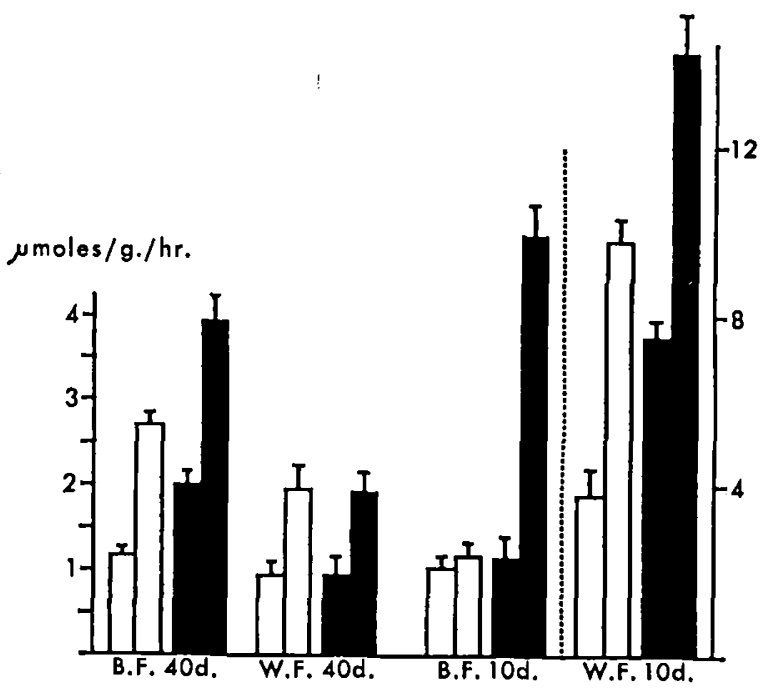

Fig. 5. Effect of injecting $5 \mathrm{mg}$ cortisone acetate $/ 100 \mathrm{~g}$ body weight on days 8 and 9 on the response of white and brown adipose tissue to ACTH $(10 \mu \mathrm{g} / \mathrm{ml})$. Ordinates: $\mu$ moles glyccrol $/ \mathrm{g}$ tissue/hr. White: Normal rats. Shaded: Rats injected with cortisone on days 8 and 9. The first column of each pair indicates the spontaneous rate of lipolysis, the second the rate after ACTH addition. B.F. 40, W.F. 40: Brown and white fat from rats aged 40 days. B.F. 10, W.F. 10: Brown and white fat from rats aged 10 days. Each column is the mean of 6-7 determinations.

Brown adipose tissue can be made responsive to ACTH as early as day 10 by injecting rats with cortisone for 2 days before the experiment (Fig. 5). This treatment also enhances the rate of lipolysis in white adipose tissue but does not further increase the responsiveness of this tissue to ACTH. This is not true for glucagon.

Brown adipose tissue from rats aged 40 days that had received two injections of cortisone $(5 \mathrm{mg} / 100 \mathrm{~g} / 24 \mathrm{hr}$ ) on days 8 and 9 showed still greater responsiveness to ACTH and had a higher rate of spontaneous lipolysis than the same type of tissue from untreated animals.

\section{Discussion}

It is generally accepted that the substance finally responsible for activating lipolysis in adipose tissue is cyclic AMP produced by adenyl cyclase and that the lipolytic hormones all act by activating this cyclase [1]. It has also been postulated that the receptor site for the different hormones is not the same, and some evidence for this has been published recently [1]. Our results are further confirmation of this postulate. They show that in brown adipose tissue development is such that glucagon and ACTH have no effect in the suckling period, while in white adipose tissue only glucagon is 
ineffective. There is considerable evidence for a change in adrenal cortical function between birth and weaning in the rat [11]. It appears that adrenal cortical hormones are produced at a lesser rate at that time since it is possible to speed up maturation of several enzyme systems and functions by corticoid administration [5]. In the experiments presented here, it was also possible to obtain a premature response of brown adipose tissue to ACTH by cortisone administration. This indicates that the adrenal cortex in some way affects the receptor sites of the cyclase in brown adipose tissue, making it more responsive to ACTH on day 10 postnatally. The transient response of brown adipose tissue to ACTH in the newborn rat might also be explained in that way since corticoids are known to be abundantly released at birth [11]. The fact that the effect of cortisone injection on days 8 and 9 still persists 30 days later indicates that this hormone in some way permanently alters brown adipose tissue when administered at that early age. Further work is required to determine the mechanism of this effect. There are some indications that hormone-sensitive lipase is involved since the activity of this enzyme is increased three times above normal values in adipose tissue of 10-day-old rats treated with corticosterone [2].

It seems permissible to conclude from our results that not only are the receptor sites of cyclase (or a substance between the lipolytic agent and the enzyme) for ACTH and norepinephrine different, but evidently they also differ for ACTH and glucagon as evidenced by the response to cortisone. In addition, it may also be postulated that the receptor sites of cyclase of brown adipose tissue and white adipose tissue are not the same.

It is difficult to correlate the findings reported in this paper with changes in enzyme activity as reported previously. From the low activity of hormone-sensitive lipase in adipose tissue in the suckling period, we would have expected the effects of all lipolytic agents to be low. Since, however, we now know that when we measure hormone-sensitive lipase activity we are really determining the rate of formation of cyclic AMP, further work on the development of cyclase activity is required. In addition, phosphodiesterase activity, in other words, the rate of breakdown of cyclic AMP, is greater in the suckling period than later in life. The changes in the response to lipolytic agents do not correlate very well with these changes in enzyme activities. In brown adipose tissue, if we leave out the newborn period, some correlation does exist, since both the rate of spontaneous lipolysis and the rate of lipolysis in- duced by lipolytic agents seem to increase with age. This is not true for subcutaneous white adipose tissue in which the rate of spontaneous lipolysis decreases with age and where lipolytic agents, excepting glucagon, but including norepinephrine [6], are at least equally effective in older and younger rats.

An explanation for this difference between the two tissues might be sought, at least in part, in the difference in morphological development. Cell size in white adipose tissue increases considerably postnatally, while the size of brown adipose tissue cells, although also increasing, shows no striking age difference [6]. In other words, a single white adipose tissue cell from a very young rat is not only smaller but contains less fat and more cytoplasmic proteins. The activity of enzymes related to lipolysis (hormone-sensitive lipase) is low per unit cytoplasmic protein but probably high per one cell. Hence, even though the rate of lipolysis per unit of cytoplasmic protein may be low in suckling rats, it is actually high per adipose tissue cell. A similar change was observed with age for the rate of fatty acid synthesis in white adipose tissue [4].

\section{Summary}

The rate of glycerol release in vitro from brown, subcutaneous, epidydimal, and ovarian adipose tissue was examined during postnatal development of the rat. Brown adipose tissue did not respond to glucagon and ACTH between days 2 and 20 but was responsive on postnatal day 1 and after day 20. Injection of cortisone on days 8 and 9 induced a premature response to ACTH but not to glucagon in 10-day-old rats and increased the response to ACTH on day 40.

Subcutaneous white adipose tissue was transiently responsive to glucagon between days 20 and 40 and then again was insensitive to this hormone. Epididymal and ovarian adipose tissue became more responsive to glucagon with age.

The ACTH sensitivity of subcutaneous white adipose tissue was greatest in the suckling period.

\section{References and Notes}

1. Birnbaumer, L., ANd Rodbell, M.: Adenyl cyclase in fat cells. II. Hormone receptors. J. Biol. Chem., 244: 3477 (1969).

2. Hann, P. Adipose tissue hormone sensitive lipase during development of the rat. Experientia, 21: 634 (1965).

3. Hahn, P., AND Drahota, Z.: The activities of citrate cleavage enzymes, acetylCoA synthetase and lipoprotein lipase in white and brown adipose tissue of the rat during development. Experientia, 22: 706 (1966).

4. Hahn, P., Drahota, Z., Skala, J., and Towell, M. E.: The effect of cortisone on brown adipose tissue from infant rats. 
Norepinephrine content and its action in vitro. Can. J. Physiol. Pharmacol., 47: 975 (1969).

5. HaHN, P., AND Koldovsky, O.: Utilization of Nutrients during Postnatal Development. (Pergamon Press, Oxford, 1966).

6. Hahn, P., Skala, J., Vizek, K., and Novak, M.: Changes in the reactivity of white and brown adipose tissue in vivo and in vitro to adrenaline and noradrenaline during postnatal development of the rat. Physiol. Bohemoslov., 14: 546, (1965).

7. Hull, D.: The structure and function of brown adipose tissue. Brit. Med. Bull., 22: 92 (1966).

8. Jelinkova, M., and Stuchlikova, E.: Age changes in the metabolism of adipose tissue. Exp. Gerontol., 3: 193 (1968).

9. Novak, M.: Colorimetric ultramicro method for the determination of free fatty acids. J. Lipid Res., 6: 431 (1965).

10. Novak, M., Hahn, P., and Melichar, V.: Glycerol and free fatty acid content and release from human adipose tissue. Biol. Neonatorum, 8: 253 (1965).

11. Philpott, J. E., Zarrow, M. X., And Denenberg, V. H.: Pre- vention of drop in adrenocortical activity in the 7-day old rat by pretreatment with ACTH. Proc. Soc. Exp. Biol. Med., 131: 26 (1969).

12. Hahn, P., and Skala, J.: The development of $3{ }^{\prime}, 5^{\prime}$-cyclic nucleotide phosphodiesterase in white and brown adipose tissue of the rat. Experientia, 26: 1300 (1970).

13. Armour, Calbiochem, Los Angeles, Calif.

14. Calbiochem.

15. Boehringer Mannheim Company, New York, N.Y.

16. IEC Company, Needham Heights, Mass.

17. This investigation was supported by Canadian Medical Research Council Grant no. MA-3713.

18. Medical Research Council of Canada Associate.

19. Requests for reprints should be addressed to: P. Hahn, M.D., Department of Obstetrics \& Gynecology, Willow Pavilion, Vancouver General Hospital, Vancouver, British Columbia, Canada.

20. Accepted for publication April 13, 1970. 